\title{
Comparative analysis of unemployment and inflation in Mexico
}

\section{Analisis comparativo del desempleo y la inflacion en México}

\author{
CASTRO-VALENCIA, Alberto Merced*† \\ Universidad Autónoma de Guadalajara \\ ID $1^{\text {st }}$ Author: Alberto Merced, Castro-Valencia / ORC ID: 0000-0001-8160-9077, arXiv Author ID: doctorcucea, CVU \\ CONACYT ID: 222325
}

DOI: $10.35429 / J I E C .2019 .5 .3 .27 .37$

Received June 07, 2019; Accepted November 15, 2019

\begin{abstract}
The article examines, based on panel regressions, the long-term relationship between inflation and economic growth based on information for 70 countries and annual data for 1950-2010 The results do not find evidence of a significant trade-off between in fl ation and long-term growth for this sample and period, except if national experiences with average annual in $\mathrm{fl}$ ations above the annual $65 \%$ threshold are included. That is, outside regimes with persistently very high rates of inflation, there is no systematic or significant inverse relationship between inflation and the growth rate of productive activity. The absence of such long-term trade-off for the aggregate panel is far from implying that for any individual economy the inflation undermines its growth only if it exceeds the $65 \%$ per annum The analysis by groups of countries reveals that the value of the threshold of significance is a function of the current monetary regime.
\end{abstract}

Trade-off, inflation and economic growth, Panel regressions, Monetary regimes, Latin American economies

\begin{abstract}
Resumen
El artículo examina, en base a regresiones de panel, la relación a largo plazo entre la inflación y el crecimiento económico basada en información de 70 países y datos anuales para 1950-2010. Los resultados no encuentran evidencia de una compensación significativa entre la inflación y el largo plazo. crecimiento a largo plazo para esta muestra y período, excepto si se incluyen experiencias nacionales con inflaciones anuales promedio por encima del umbral anual del $65 \%$. Es decir, fuera de los regímenes con tasas de inflación persistentemente muy altas, no existe una relación inversa sistemática o significativa entre la inflación y la tasa de crecimiento de la actividad productiva. La ausencia de tal compensación a largo plazo para el panel agregado está lejos de implicar que para cualquier economía individual la inflación socava su crecimiento solo si excede el $65 \%$ anual. El análisis realizado por grupos de países revela que el valor del umbral de importancia es una función del régimen monetario actual.
\end{abstract}

Compensación, inflación y crecimiento económico, regresiones del panel, regímenes monetarios, economías latinoamericanas

Citation: CASTRO-VALENCIA, Alberto Merced. Comparative analysis of unemployment and inflation in Mexico. JournalInternational Economy. 2019. 3-5:27-37

\footnotetext{
* Correspondence to Author (castroalberto172@gmail.com)

$\dagger$ Researcher contributing first Author.
} 


\section{Introduction}

The conventional practice of macroeconomic policy since the second half of the twentieth century has been largely shaped by the conviction that inflation is a monetary phenomenon and that there is an inverse relationship between inflation and economic growth in different temporal horizons Regarding this relationship, three different positions can be identified in the literature.

The first is that moderate inflation can have a favorable effect on capital accumulation due to the portfolio recomposition effect postulated by Tobin (1965). The basic idea of this approach, based on the growth model of Solow (1956) and Swan (1956), is that individuals keep money as an asset, so increases in inflation, by eroding its value faster, induce a portfolio recomposition towards the purchase of physical assets, machinery and equipment for productive activities. This greater accumulation of capital has an impact on an increase in the economic growth rate in the short term.1 A conclusion in a similar direction can be derived from the notion that growth requires a transformation of the productive structure. This transformation is accompanied by favorable changes in prices or relative profitability of different industries to attract resources - labor and capital - to selected activities. These changes in relative prices may push up the price level.

A second position argues that inflation does not necessarily have an impact, neither favorable nor unfavorable, on long-term economic growth. Among the proponents, already in good time behind this position, is Sidrauski (1967) that based on a model of optimizing agents based on the Ramsey model (1928), where the possession of money is motivated from the fl ow of services provided, argues that the capital accumulation rate, and therefore the growth of the economy, is independent of the inflation rate. The third position is that inflation is inescapably harmful to economic growth. 2 This is the most common position today, not only in the business press but among a considerable set of officials in charge 1 Algan and Ragot (2010) illustrate the Tobin effect in a theoretical model where precautionary savings decisions by agents facing uncertainty in the absence of complete markets, give rise to a positive relationship between growth and inflation, for moderate levels of inflation.
On the other hand, Mallik and Chowdhury (2001) find empirical evidence of a positive relationship between both variables in the case of four countries in South Asia.

2 See, for example, the work of Andrés and Hernando (1999), who conclude that there is a causal relationship, of a negative and statistically significant sign, of the inflation towards growth, which is robust to the exclusion of episodes of high inflation. of the conduct of macroeconomic policy in multiple countries. In fact, this position tends to be the central guide for the behavior of central banks in our region and is often accompanied by the explicit or implicit assumption that high and sustained economic growth requires as a necessary condition - and for some cases They seem to argue that it is also sufficient - a low and stable inflation.

In less stringent versions of this last position, it is affirmed that only when a certain threshold is exceeded does the inflation significantly and adversely affect the efficient allocation of resources, to the point of curbing investment and the pace of economic expansion (Sarel, 1995). If so, the threshold remains to be identified, in international comparisons, from which the greatest inflation reduces

Notes: the regression equation is: GDP growth $=4.33-0.0210 *$ (inflation), where the inflation coefficient has a standard error of 0.0030 , which implies a t-statistic of -7.3 . The coefficient of determination (R2) of the linear regression is 0.0111 , and the root of the mean square error is 1,2365 . The sample includes 70 countries, based on real data in constant dollars and consumer price indices. Source: Own elaboration based on data from Ilzeki, Reinhart and Rogo ff (2008), Reinhart and Rogo ff (2010) and The Conference Board (2011).

4 For each country, the average of GDP growth and the in $\mathrm{fl}$ action of consumer prices over the period 1950-2011 are calculated. The median is preferred as a measure of central tendency, since it is less sensitive than the average to the occurrence of extreme observations. 
To delve into this, the graph also includes the result of the simple linear regression between both variables estimated by ordinary least squares. This line, in contrast, suggests a slight inverse correlation between inflation and growth medians, as well as a $1 \%$ increase in the median annual inflation associated with a $2.1 \%$ reduction in the median growth. Although this result is statistically significant, with a t-statistic value equal to 7.03 , the regression adjustment is very poor, since the coefficient of determination (R2) is only $1.13 \%$, and does not pass the conventional tests of correct specification. In fact, both the axes of graph 1 and its scatter plot include box diagrams that formally account for the distribution of both variables. 5

These point out that the joint distribution, and the correlation, between both variables is influenced by the occurrence of extreme values.

Consequently, and in order to more systematically explore the hypothesis about the significance and direction of the relationship between inflation and economic growth, the sample was segmented with subgroups of economies, in some sense homogeneous as to the conduct of their monetary policy . In this regard, and although, both the objectives and the instruments of monetary policy have evolved, it should be asserted that throughout the period analyzed the central banks have oriented said policy to keep the inflation at the lowest possible level. In this effort, in general its action sought to provide a nominal anchor to meet the inflationary expectations. In the adoption of this strategy, the choice of the exchange rate regime is prominent (see, among others, White, 2013).

Figure 2 shows the evolution of the medians (of the selected sample of countries) of the annual growth of real GDP and of the inflation over the course of 1951-2010. First, there is an important change in the trend of both variables in the early 1970s, linked to the collapse of the Bretton Woods regime and the first oil shocks. In effect, the impact of these phenomena is reflected in a rise in the level of inflation, as well as a decrease in the pace of global economic activity; changes that marked the end of the so-called golden decades of economic performance 5 The ends of the "solid rectangles" drawn on the vertical and horizontal axis show the 25 th and 75 th percentiles of the corresponding variable, while the inner line shows the median of the distribution.
On the other hand, the termination of the lines at each end of these boxes shows the adjacent values, calculated as $3 / 2$ times the interquartile range. mine ranging from the first half of the 1950s to 1973. The graph also indicates a certain change in the relationship between inflation and the pace of economic activity. To what extent was the intensity or direction of the relationship between inflation and global economic growth significantly altered? It is part of the questions for which this work provides inputs for your response.

S ource: own elaboration based on data from Ilze ki, Reinhart and Rogo ff (2008), Reinhart and Rogo ff (2010) and The Conference Board (2011).

6 The graph also shows that, in addition to the supply shocks produced in the 1970s following the oil embargo, the various crises of the last 30 years have influenced the evolution of inflation and economic growth, and probably also in their interaction.

The previous discussion reflects to some extent the restrictions inherent in what Fleming (1962) and Mundell (1963) called the "Impossible Trinity," according to which a country can adopt at most two of the following three policies: 1) free mobility of capital in the balance of payments; 2) fixed nominal exchange rate, and 3) monetary autonomy, understood as the ability to set the nominal interest rate different from that which governs transactions in the international financial market. In fact, the evolution of the international financial regime can be periodized according to the weighting assigned to each of these three policies.

This section explores the nature of the relationship between inflation and growth using the taxonomy provided by the different combinations of policy provided regarding the exchange rate regime, the degree of opening of the capital account and monetary autonomy.

First, the relationship between both variables at an aggregate level is explored in depth, both for the global sample of countries and the subsample of Latin American countries, without any restriction on the range of the two variables considered. 
Subsequently, the regression analysis is repeated but restricting the samples in order to successively exclude from it the observations whose inflation is extreme in the sense that it exceeds certain ranges. These ranges are gradually being reduced downwards in each round of estimation of the correlation coefficients from the panel data.

As mentioned, the extreme observations in the data panel skew the estimated correlation coefficients. An alternative to correct this bias is to perform the statistical analysis based on a transformation of the initial variables, which reduces the effect of the observations or extreme values. For the present study, the procedure of replacing the usual measurement of the annual inflation of the consumer price index $(\pi)$ was adopted by its non-linear transformation that is usually identified as a measure of the inflationary $\operatorname{tax}[\pi /(1+\pi)]$.

The result of the previous procedure is presented in Figure 3. The first element to highlight is that the proposed transformation attenuates the impact of extreme values on inflation. However, the regression coefficient linear suggests the persistence of a negative relationship between the variables, which is statistically significant, the regression adjustment is even worse than the one observed before performing the transformation. To refine the analysis, in the table 1 the results of the panel regressions are offered between the observations of the annual median GDP growth and the inflation tax, restricting the sample to different levels of inflation. The first line reports the results for the entire panel. The second reports the results when the sample is restricted to Latin American countries.

Source: own elaboration based on data from Ilze ki, Reinhart and Rogo ff (2008), Reinhart and Rogo ff (2010) and The Conference Board (2011).

6 The graph also shows that, in addition to the supply shocks produced in the 1970s following the oil embargo, the various crises of the last 30 years have influenced the evolution of inflation and economic growth, and probably also in their interaction.
The previous discussion reflects to some extent the restrictions inherent in what Fleming (1962) and Mundell (1963) called the "Impossible Trinity," according to which a country can adopt at most two of the following three policies: 1) free mobility of capital in the balance of payments; 2) fixed nominal exchange rate, and 3) monetary autonomy, understood as the ability to set the nominal interest rate different from that which governs transactions in the international financial market. In fact, the evolution of the international financial regime can be periodized according to the weighting assigned to each of these three policies.

This section explores the nature of the relationship between inflation and growth using the taxonomy provided by the different combinations of policy provided regarding the exchange rate regime, the degree of opening of the capital account and monetary autonomy.

First, the relationship between both variables at an aggregate level is explored in depth, both for the global sample of countries and the subsample of Latin American countries, without any restriction on the range of the two variables considered. Subsequently, the regression analysis is repeated but restricting the samples in order to successively exclude from it the observations whose inflation is extreme in the sense that it exceeds certain ranges. These ranges are gradually being reduced downwards in each round of estimation of the correlation coefficients from the panel data.

As mentioned, the extreme observations in the data panel skew the estimated correlation coefficients. An alternative to correct this bias is to perform the statistical analysis based on a transformation of the initial variables, which reduces the effect of the observations or extreme values. For the present study, the procedure of replacing the usual measurement of the annual inflation of the consumer price index $(\pi)$ was adopted by its non-linear transformation that is usually identified as a measure of the inflationary $\operatorname{tax}[\pi /(1+\pi)]$.

The result of the previous procedure is presented in Figure 3. The first element to highlight is that the proposed transformation attenuates the impact of extreme values on inflation. However, the regression coefficient 
Notes: the regression equation is: growth $=4.30-0.0138 *$ (inflationary tax), where the inflation coefficient has a standard error of 0.0025 , which implies a t-statistic of -5.58 . The coefficient determination R2 of the linear regression is 0.0071 , and the root of the mean square error is 1.2391 . The sample includes 70 countries, based on real data in constant dollars and consumer price indices. Source: Own elaboration based on data from Ilze ki, Reinhart and Rogo ff (2008), Reinhart and Rogo ff (2010) and The Conference Board (2011).

It is important to highlight the contrast with the regressions in Figures 1 and 3. In these, the median of each country throughout the period represents an observation, and the coefficients are estimated using ordinary least squares. In contrast, annual information and panel structure are exploited in Table 1, so that for each country and for each year there is an observation, and the coefficients are estimated using panel regressions.

Correlación entre impuesto inflacionario y crecimiento económico, 1951-2010 Rango impuesto inflacionario

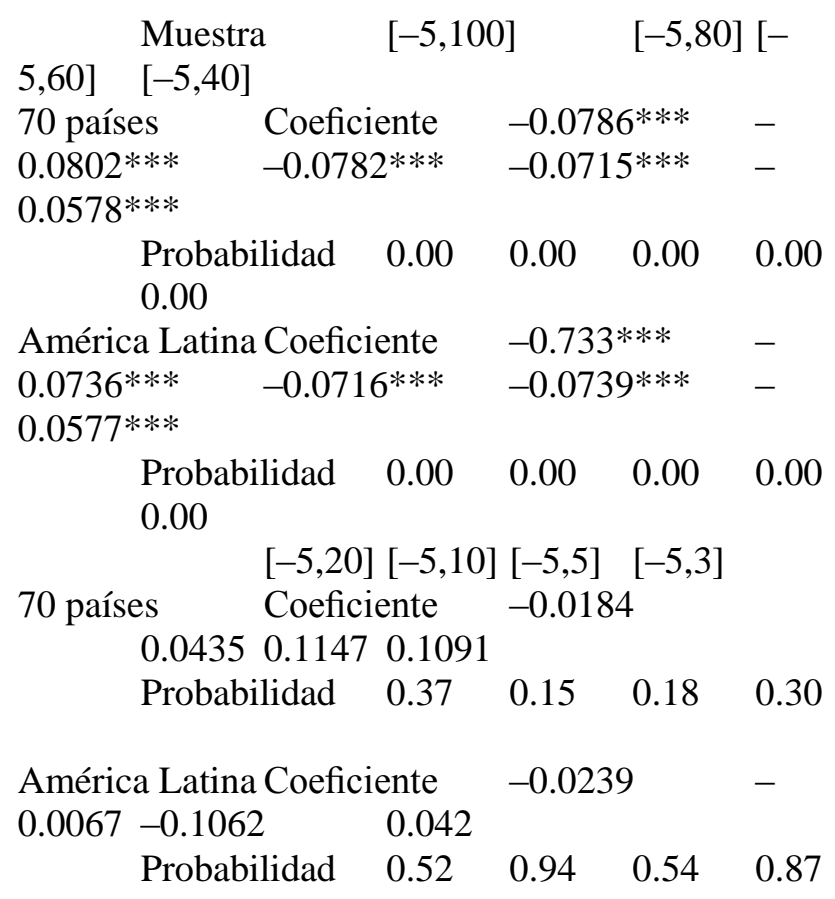

Source: own elaboration based on data from Ilze ki, Reinhart and Rogo ff (2008), Reinhart and Rogo ff (2010) and The Conference Board (2011).
6 The graph also shows that, in addition to the supply shocks produced in the 1970s following the oil embargo, the various crises of the last 30 years have influenced the evolution of inflation and economic growth, and probably also in their interaction.

The previous discussion reflects to some extent the restrictions inherent in what Fleming (1962) and Mundell (1963) called the "Impossible Trinity," according to which a country can adopt at most two of the following three policies: 1) free mobility of capital in the balance of payments; 2) fixed nominal exchange rate, and 3) monetary autonomy, understood as the ability to set the nominal interest rate different from that which governs transactions in the international financial market. In fact, the evolution of the international financial regime can be periodized according to the weighting assigned to each of these three policies.

This section explores the nature of the relationship between inflation and growth using the taxonomy provided by the different combinations of policy provided regarding the exchange rate regime, the degree of opening of the capital account and monetary autonomy.

First, the relationship between both variables at an aggregate level is explored in depth, both for the global sample of countries and the subsample of Latin American countries, without any restriction on the range of the two variables considered. Subsequently, the regression analysis is repeated but restricting the samples in order to successively exclude from it the observations whose inflation is extreme in the sense that it exceeds certain ranges. These ranges are gradually being reduced downwards in each round of estimation of the correlation coefficients from the panel data.

As mentioned, the extreme observations in the data panel skew the estimated correlation coefficients. An alternative to correct this bias is to perform the statistical analysis based on a transformation of the initial variables, which reduces the effect of the observations or extreme values. For the present study, the procedure of replacing the usual measurement of the annual inflation of the consumer price index $(\pi)$ was adopted by its non-linear transformation that is usually identified as a measure of the inflationary tax $[\pi /(1+\pi)]$. 
The result of the previous procedure is presented in Figure 3. The first element to highlight is that the proposed transformation attenuates the impact of extreme values on inflation. However, the regression coefficient

Notes: the regression equation is: growth $=4.30-0.0138 *$ (inflationary tax), where the inflation coefficient has a standard error of 0.0025 , which implies a t-statistic of -5.58 . The coefficient determination R2 of the linear regression is 0.0071 , and the root of the mean square error is 1.2391 . The sample includes 70 countries, based on real data in constant dollars and consumer price indices. Source: Own elaboration based on data from Ilze ki, Reinhart and Rogo ff (2008), Reinhart and Rogo ff (2010) and The Conference Board (2011).

Note: the asterisks in the coefficients denote their statistical significance: $* * * 99 \%$, ** $95 \%, * 90 \%$. The figure below the coefficient indicates the probability with which, under the null hypothesis that the coefficient is equal to zero, the estimated coefficient value can be observed. The ranges in parentheses are about inflation.

Source: own elaboration based on data from Ilzeki, Reinhart and Rogo ff (2008), Reinhart and Rogo ff (2010) and The Conference Board (2011).

Consistent with the evidence shown in graphs 1 and 3, with the transformation of the inflation variable, both for the panel of 70 countries and for the subsample of Latin American countries, the results of the regressions confirm an inverse relationship (that is, a negative coefficient) between the inflationary tax and the statistically significant economic growth for the entire panel.

Table 1, from its second column, offers the result of the correlation coefficient and its significance when the sample is restricted to inflationary tax values to successively narrower ranges. This sequence is made by eliminating the observations that exceed the ceilings that are bounding down, starting with 100 , until reaching 3 in the last column of the table,
7 For all cases the coefficients were estimated using both fixed and random effects; however, only the coefficient selected by the Hausman contrast (1978) is reported. The results of the model selection are not reported, but are available for consultation through the authors. in the infe block Source: own elaboration based on data from Ilze ki, Reinhart and Rogo ff (2008), Reinhart and Rogo ff (2010) and The Conference Board (2011).

The estimated correlation coefficients between the growth rate and the inflation tax for the entire panel appear in the upper block of table 2 , discriminating according to the independence of the monetary policy; while the lower block offers the results using only data from Latin American countries. As in the previous case, the columns present the correlation coefficients and their significance in different ranges of the inflationary tax.

The first element that stands out is that, as mentioned, the inflation in countries without monetary autonomy is considerably less than that observed in the group with monetary autonomy, so it is not possible to estimate the correlation in the ranges More spacious. In addition, with the exception of the smallest range in Latin America, the coefficients are not significantly different from zero. In contrast, among countries with monetary autonomy it is confirmed the relationship described above, where both the magnitude of the coefficients and their significance are reduced to the extent that the in $\mathrm{fl}$ action range is restricted, pointing to the existence of a threshold of significance in the relationship between the two variables.

Note: the asterisks next to the coefficients denote the statistical significance: $* * * 99 \%$, ** 95\%,* $90 \%$ The figure below the coefficient indicates the probability with which, under the null hypothesis that the coefficient is zero, the estimated value obtained from the coefficient is observed. The ranges in parentheses are about inflation. Source: Own elaboration based on data from Ilze ki, Reinhart and Rogo ff (2008), Reinhart and Rogo ff (2010) and The Conference Board (2011).

Comparing the results of the complete panel with those of Latin America, it can be seen that the magnitude of the correlation coefficients between inflation and economic growth is greater in the entire panel. 
At the same time, while in the full panel the relationship remains significant in the range of between -5 and 20, this is not the case for Latin America. This result attracts attention, since historically inflation has been considered a topic of first importance in this region. One possible explanation is the presence of other factors that may be affecting the interaction between inflation and growth, but whose effect is not captured in this analysis.

Without prejudice to the strategies that imply the absence of monetary autonomy, it is of particular interest to study in detail the institutional arrangements in force among countries that have decided to maintain an independent monetary policy. In the vast majority of these cases, the main objective of independent monetary policy is the search for price stability. Although, as Reinhart and Reinhart (2003) argue, the solution to the socalled international finance trilemma does not necessarily imply the adoption of pure regimes. For mere exposure purposes, the sample of the panel of countries during the last forty years is classified according to three regimes that represent extremes in the scope of possible policies under the trilemma.

In the first regime a fixed nominal exchange rate is combined with a closed capital account. This situation was prevalent during the regime that Bretton Woods, in force from the end of World War II until 1971. The second regime is the polar case, where a floating exchange rate is adopted and free capital mobility is allowed, a situation that To a large extent, it has characterized the international financial system since the mid-1990s. Finally, it is considered a third regime, in which a floating exchange rate is maintained, but restrictions on the free entry and exit of capital are maintained. . This situation, although rare today, characterized several countries in South America until the end of the 1990s.

To make this taxonomy operational, the classification of de facto exchange rate regimes of the International Monetary Fund (IMF) reported by Ilzetzki, Reinhart and Rogoff (2008) and the capital account opening index developed by Chinn and Ito are used (2008). In particular, both pure and managed float regimes are classified as a floating type. while the opening index of Chinn and Ito (2008) is normalized so that their values are between 0 and 1 , which represent a fully closed and open capital account respectively, and is classified as open for those cases where The index is greater than 0.5 .

The relationship of economic growth and inflation, based on this taxonomy, is illustrated in Figure 5. The first element to highlight is the heterogeneity within the group of countries with monetary authority. In this group, the median growth has been relatively constant between 3.5 and 4 percent over the period, but the trajectories under different regimes have been quite different. On the other hand, for the three regimes there is a significant decrease in the median inflation, which began to be observed in the 1980s in countries with regime II, and is consolidated at a level lower than $10 \%$ per year in the other two regimes towards the end of the 1990s. However, the experience prior to the general decline in inflation is very different, which explains why with a median of $16.5 \%$ per year, the inflation under regime III is almost four times higher than $4.4 \%$ registered by the regime II countries.

Note: Regime I. Fixed exchange rate and closed capital account; Regime II. Flexible exchange rate and open capital account, and Regime III. Flexible exchange rate and closed capital account. Source: Own elaboration based on data from Ilzeki, Reinhart and Rogo ff (2008), Reinhart and Rogo ff (2010) and The Conference Board (2011).

One possible explanation is that, as mentioned, until the second half of the 1990s, a significant part of the countries under regime III are Latin American, several of which suffered episodes of very high in fl ation. Among them are the cases of Argentina, Brazil and Mexico during the 1980s.

The second feature that attracts attention is that there is no inverse correspondence between inflation and economic growth between different regimes of monetary autonomy. In fact, despite the relatively low level of inflation they had, the countries of regime II registered the lowest economic growth rate among countries with monetary autonomy. This may have to do with the volatility caused by the free mobility of capital. 
Table 3 shows the correlation coefficients of the three groups. For the complete panel, it is observed that in the regimes with a closed capital account (I and III) a non-linear relationship is confirmed in which the magnitude and significance of the correlation between inflation and growth is reduced to the extent that they are excluded cases with higher levels of inflation. At the same time, and as noted above, the evidence indicates that this relationship is less intense for Latin American countries. It is notable that under regime II, where monetary autonomy is achieved through the combination of a flexible exchange rate and an open capital account, there seems to be no significant inverse relationship between inflation and economic growth.

The theoretical literature of the late 1960s argued in favor of monetary autonomy in an environment of flexible exchange rates, on the grounds that monetary policy would be able to respond adequately to heterogeneous shocks. The convenience of this regime was preached in the stabilization mechanism provided by the uncovered interest rate parity, according to which the arbitration opportunities caused by differences in interest rates between countries would be eliminated by exchange rate adjustments.

Notwithstanding the foregoing, the volatility experienced since the end of the 1990s, as well as the empirical evidence indicating that the discounted interest rate parity is only observed over very long periods, has resulted to rethink the desirability of adopting extreme positions (corner solutions) to the trilemma of international finance. Hence, the attention of various countries in the adoption of intermediate, floating, but managed exchange rate regimes and capital flow management measures to ensure effective monetary autonomy is further understood.Correlation between inflation tax and economic growth according to monetary autonomy regime, 19702010

\section{Panel 70 countries}

Sample Range $[-5,100][-5,80][-5,60][-5,40]$

Regime I Coefficient $-0.0889 * * *-0.0886 * * *-$ $0.0893 * * *-0.0915 * * *-0.0892 * * *$

Probability 0.00000 .00000 .00000 .00000 .0040

Regime II Coefficient........ - $0.0834 *-0.074 * * *$ Probability........ 0.08600 .0030

Regime III Coefficient... $-0.0883 * * *-0.0973 * * *$ $-0.1151 * * *-0.1332 * * *$
Probability... 0.00000 .00000 .00000 .0000

$[-5.20][-5.10][-5.5][-5.3]$

Regime I Coefficient - 0.04810 .05440 .13440 .2899

Probability 0.37600 .51800 .60500 .5050

Regime II Coefficient $-0.0597-0.0347-0.1477$ 0.0509

Probability 0.32700 .66800 .25500 .8510

Regime III Coefficient $-0.1444 * * *-0.2306 *-$ $0.1772-0.3246$

Probability 0.00000 .5400 .31600 .2630

Latin America

Sample $[-5,100][-5,80][-5,60][-5,40]$

Regime I Coefficient $-0.0692 * * *-0.0699 * * *-$ $0.0575 * *-0.0472-0.0177$

Probability 0.00000 .00000 .03500 .12900 .6640

Regime II Coefficient........ $-0.0706-0.016$

Probability ......... 0.1410 .318

Regime III Coefficient... $-0.0669 * * *-0.0711 * * *$ $-0.0842 * * *-0.0974 * *$

Probability... 0.00200 .00100 .00000 .0150

$[-5.20][-5.10][-5.5][-5.3]$

Regime I Coefficiency $-0.0022-0.1373-0.0973 \ldots$

Probability $0.98600 .48500 .9090 \ldots$

Regime II Coefficiency $-0.0884-0.1321-0.3166 \ldots$

Probability $0.4730 .4490 .559 \ldots$

Regime III Coefficiency $-0.1148 *-0.1891 .008 \ldots$

Probability $0.05800 .72600 .5460 \ldots$

Note: the asterisks next to the coefficient denote their statistical significance: $* * * 99 \%$, ** 95\%,

$* 90 \%$ The figure below the coefficient indicates the probability with which, under the null hypothesis that the coefficient is zero, the estimated value in the regression is observed. The ranges in parentheses are about annual inflation.

Regime I. Fixed exchange rate and closed capital account; Regime II. Flexible exchange rate and

\section{Referencias}

Algan, Y. y Ragot, X., 2010. Monetary Policy with Heterogeneous Agents and Bo- rrowing Constraints. Review of Economic Dynamics, 13(2), pp. 295-316.

Andrés, J. y Hernando, I., 1999. Does Inflation Harm Economic Growth? Evidence for the OECD”. En: Feldstein, M. (editor). The Costs and Benefits of Price Stability. Chicago IL: The University of Chicago Press, pp. 315-41.

Balassa, B., 1964. The Purchasing-Power Parity Doctrine: A Reappraisal. Journal of Political Economy, 72(6), 1 de diciembre, pp. 584-96.

Barro, R.J., 2013. Inflation and Economic Growth. Annals of Economics and Finance, 14(1), pp. 121-44. 
Bruno, M. y Easterly, W., 1998. Inflation Crises and Long-run Growth. Journal of Mo- netary Economics, 41, pp. 3-26.

Chinn, M. e Ito, H., 2008. A New Measure of Financial Openness. Journal of Compa- rative Policy Analysis, 10(3), septiembre, pp. 309-22.

Erosa, A. y Ventura, G., 2002. On Inflation as a Regressive Consumption Tax. Journal of Monetary Economics, 49(4), pp. 761-95.

Fleming, J.M., 1962. Domestic Financial Policies Under Fixed and Under Floating Exchange Rates. Staff Papers - International Monetary Fund, 9(3), noviembre, pp. 369-80.

Hausman, J.A., 1978. Specification Tests in Econometrics. Econometrica, 46(6), pp. 125171. Ilzetzki, E., Reinhart, C.M. y Rogoff, K.S., 2008. Exchange Rate Arrangements Entering the 21st. Century: Which Anchor Will Hold?" [mimeo]. Cambridge, MA:Harvard University.

Koenker, R. y Bassett, G., 1978. Regression Quantiles. Econometrica, 46(1), pp. 33-50. Mallik, G. y Chowdhury, A., 2001. Inflation and Economic Growth: Evidence from Four South Asian Countries. Asia Pacific Development Journal, 8(1), pp. 123-35. Mundell, R.A., 1963. Capital Mobility and Stabilization Policy under Fixed and Flexible Exchange Rates. Canadian Journal of Economics and Political Science, 29, noviembre, pp.475-85.

Ramsey, F.P., 1928. A Mathematical Theory of Saving. The Economic Journal, 38(152), pp. 543-59.

Reinhart, C.M. y Reinhart, V.R., 2003. Twin Fallacies about Exchange Rate Policy in Emerging Markets [NBER Working Paper Series no. 9670]. National Bureau of Economic Research (NBER), Cambridge, MA.

Reinhart, C.M. y Rogoff, K.S., 2010. From Financial Crash to Debt Crisis [NBER Working Paper Series no. 15795]. NBER, Cambridge, MA.

Sarel, M., 1995. Nonlinear Effects of Inflation on Economic Growth [IMF Working Paper no. WP/95/56]. International Monetary Fund (IMF), Washington DC. Samuelson, P.A., 1964. Theoretical Notes on Trade Problems. The Review of Economics and Statistics, 46(2), 1 de mayo, pp. 145-54.
Sidrauski, M., 1967. Rational Choice and Patterns of Growth in a Monetary Eco- nomy. The American Economic Review, 57(2), 1 de mayo, pp. 534-44.

Solow, R.M., 1956. A Contribution to the Theory of Economic Growth. Quarterly Journal of Economics, 70(1), pp. 65-94.

Swan, T.W., 1956. Economic Growth and Capital Accumulation. Economic Record, 32(2), pp. 334-61.

The Conference Board, 2011. Total Economy Database. The Conference Board [en línea]. Disponible en: < https://www.conferenceboard.org/data/economydatabase/>. Tobin, J., 1965. Money and Economic Growth. Econometrica, 33(4), 1 de octubre, pp. 671-84 .

White, W.R., 2013. Is Monetary Policy a Science? The Interaction of Theory and Practice Over the Last 50 Years [Globalization and Monetary Policy Institute Working Paper no. 155]. Federal Reserve Bank of Dallas, Dallas, Texas.

Banco Mundial (2014). World Development Indicators Database. Disponible en: <http://www.databank.worldbank.org>

Barrañón, A. (2008). "La crisis mexicana del petróleo en el escenario de precios altos del petróleo". Razón y Palabra, MONOGRÁFICO SOBRE FILOSOFÍA Y COMUNICOLOGÍA(64).

Beteta, H. (2013). "La matriz de contabilidad social como instrumento de análisis estructural de la economía mexicana y sus aplicaciones en politica fiscal". Centro de estudios de las finanzas públicas, 10(5), 27-54.

Cardenete, M., y Delgado, M. (2011). "Análisis de la estructura de la economía georgiana". Papeles de Europa, 23, 21-42.

Chapa, J. (2000). Análisis de la Apertura Comercial en México Mediante Modelos Multisectoriales, 1970-93. (Tesis doctoral). Universitat de Barcelona, España.

Crandall, R. (2004). Mexico's Domestic Economy. En Crandall R. (Ed.), Mexico's Democracy at work: Political and Economic Dynamics. United States: Lynee Reiner Publishers.

CASTRO-VALENCIA, Alberto Merced. Comparative analysis of unemployment and inflation in Mexico. Journal- International Economy. 2019 
Gereffi, G., y Martinez, M. (2004). Mexico's Economic Transformation under NAFTA. En Crandall R. (Ed.), Mexico's Democracy at work: Political and Economic Dynamics. United States: Lynne Reiner Publishers.

Gil, G., y Chacón, S. (2008). La crísis del Petróleo en México. México: Foro Consultivo Científico y Tecnológico.

Harris, R. (2002). "Estimation of a Regionalized Mexican Social Accounting Matrix: Using Entropy Techniques to Reconcile Disparate Data Sources". Globalización Research Center, University of South Florida. Trade and Macroeconomics Division, International Food Policy Research Institute, Discussion Paper No. 97.

Hernandez, R. (2005). "The U.S.-Mexico Remittance Corridor: Lessons on shifting from informal to formal transfer systems". World Bank working paper No. 47.

INEGI (2007). "Sistema de Clasificación Industrial de América del Norte".Instituto Nacional de Estadística y Geografía, tercera edición. México: INEGI.

INEGI (2008). "Encuesta Nacional de Ingreso y Gasto de los Hogares". Instituto Nacional de Estadística y Geografía. México: INEGI . INEGI (2010a). "Cuentas de bienes y servicios 20032008". Instituto Nacional de Estadística y Geografía, Tomos I y II, Segunda versión. México: INEGI .

INEGI (2010b). "Cuentas por sectores institucionales". Instituto Nacional de Estadística y Geografía, Tomo I y II, Segunda versión. México: INEGI .

INEGI (2013). "Matriz Insumo-Producto 2008". Instituto Nacional de Estadística y Geografía, Sistema de Cuentas Nacionales de México. México: INEGI .

Jaime, C. (1992). Cosntrucción de una Matriz de Contabilidad Social para México, 1989. (Tesis de Maestría). Colegio de México, México D.F. Minzer, y Solis. (2014). "Análisis estructural de la economía mexicana. Algunas medidas de reforma fiscal y su impacto en la recaudación tributaria y la pobreza". Estudios y Perspectivas, 151.
Moreno, J. (2009). "Crisis financiera internacional y sus efectos en la economía mexicana". Economía: Teoría y Práctica, 1(Número especial).

Moreno, S. (2008). "Migración, remesas y desarrollo regional en México". Centro de estudios sociales y de opinión pública, Documento de trabajo No. 50.

Núñez, G. (2003). Un análisis Estructural y de Equilibrio General de la Economía Mexicana. (Tesis doctoral). Universidad Autónoma de Barcelona, España.

Nuñez, G., y Mendoza, V. (2008). "Matriz de contabilidad social y análisis estructural de una economía rural: el ejido Los Lirios, municipio de Arteaga, Coahuila, México".Economía: Teoría y Práctica, 28(1), 43-70.

Núñez, G., y Polo, C. (2010). "Una matriz de contabilidad social de México y un análisis estructural de la economía mexicana". Estudios sociales, 18(35), 11-52.

Polo, C. , Roland-Holst, D., y Sancho, F. (1991). "Descomposición de multiplicadores en un modelo multisectorial: una aplicación al caso español". Investigaciones Económicas, 15(1), 53-69.

Pyatt, G. (1988). "A SAM Approach to Modeling". Journal of Policy Modelling, 10(3), 327-352.

Pyatt, G., y Round, J. (1979). "Accounting and Fixed Price Multipliers in a Social Accounting Matrix Framework". The Economic Journal, 89(356), 850-873.

Rasmussen, P. (1956). Studies in Inter-Sectorial Relations. Copenhagen: Einar Harks.

Ruiz, R. (2010). "Crisis financiera mundial: impacto en la economía mexicana". Observatorio de la Economía Latinoamericana, 136.

Sobarzo, H. (1990). "A Consolidated Social Accounting Matrix for Input-output Analysis". Estudios Económicos, Colegio de México, Documento de trabajo No. 4. 
Sobarzo, H. (2007). "A General Equilibrium Analysis of the Gains from Trade for the Mexican Economy of a North American Free Trade Agreement". The World Economy, 15(1), 83-100.

Sonis, M., Hewings, G., y Sulistyowati. (1997). "The Structure of the Indonesian Economy: A generalized Structural Path Analysis". Economic Systems Research, 9, 265-280.

Stone, R. (1962). A Social Accounting Matrix for 1960. En Stone R. (Ed.), A Programme for Growth ). London: Chapman and Hall Ltd. Stone, R. (1985). The disaggregation of the household sector in the national accounts. En Pyatt, G. y Round, J. (Eds.), Social accounting matrices: A basis for planning, (145-185).

Washington, D.C., U.S.A.: World Bank Thorbecke, E. (1985). The social accounting matrix and consistency-type planning models. En Pyatt G. y Round J. (Eds.), Social accounting matrices: a basis dor planning. Washington D.C.: World Bank. 1CONAPO es el Consejo Nacional de Población, cuya misión es la planeación demográfica del país, a fin de incluir a la población en los programas de desarrollo económico y social. Proyecciones disponibles en:

http://www.conapo.gob.mx/es/CONAPO/proye cciones_datos.

2De acuerdo con el ranking 2014 del Banco Mundial en millones de dólares, siguiendo el Método Atlas. 